\title{
FEMINIZING WORLD POWER: A NEW CONSTELLATION OF WOMEN IN POLITICS?
}

\author{
MICHAEL A. PETERS \\ mpeters@waikato.ac.nz \\ University of Waikato; \\ University of Illinois at Urbana-Champaign
}

\begin{abstract}
This article charts the emergence of women leaders currently in power, the highest it has ever been with 22 female heads of state and political leaders in 2015. It canvases Fukuyama's (1988) sociobiology arguments and those of feminists on questions of women's political representation. It briefly investigates the "critical mass" argument of Kanter (1977) and others to ask whether there is a new constellation of women in politics, especially with Hillary Clinton's possible ascendancy to the US presidency, leading to the possibility of feminizing world power.
\end{abstract}

Keywords: women; world power; feminine politics; "critical mass"; Hillary Clinton

How to cite: Peters, Michael A. (2016), "Feminizing World Power: A New Constellation of Women in Politics?," Journal of Research in Gender Studies 6(2): 62-68.

Received 19 July $2016 \cdot$ Received in revised form 6 August 2016 Accepted 6 August $2016 \cdot$ Avalable online 20 August 2016

It is an interesting time in world politics. Neoliberal globalization seems on the back foot especially after an unexpected Brexit. Europe faces the prospect of realigning itself after the UK vote to leave the EU. The UK suffering from an immediate economic effect of Brexit has to renegotiate its international relations and trading agreements. The EU faces what seem insuperable problems: its Mediterranean economies are in bad shape and the EU is still recovering from the Great Recession of 2007-8. Meanwhile the Middle East is a boiling cauldron of regional, religious and ethnic conflicts involving a new round of US-Russia politics and strategic action over Assad's regime and larger regional bloc conflicts. The Syrian civil war is in its seventh year and refugees from Syrian have made up one of the largest migration crises mainly from displaced refugees in the Middle East since WWII with strong eco- 
nomic, social and security consequences for the EU. ISIL continues to grow and extend its influence in the Levant. Militant Islam with all its splinter groups continues to conduct its suicide and car bombing attacks on European civil society. There are also new crises brewing in the South China Seas with China's imperial ambitions as well as international difficulties with so-called "rogue states" like Korea. The likelihood of nuclear proliferation is probably greater at this point historically than any time since the end of WWII.

At the same time the specter of Donald Trump grows larger as the US November elections approach and the rhetoric that spills forth from him on issues of NATO, Russia, and China scare most mainstream foreign policy specialists. His threatened withdrawal of major partnerships and international treaties including the recent Paris environmental agreement poses a real cause for alarm.

The world leadership problems and issues confronting heads of state are probably more complex and intrinsically more difficult than at any time in the past. At the same time it appears that the emergence of women leaders currently in power is the highest it has ever been with the election or appointment of some twenty-two female heads of state and leaders in $2015 .{ }^{1}$ Caroline Howard and Michael K. Ozanian (2012) named "The 100 Most Powerful Women" beginning with Angela Merkel, Hillary Clinton, Dilma Rousseff, Melinda Gates, Jill Abramson, Sonia Ghandi, Michelle Obama, Christine Lagarde, Janet Napolitano, and Sheryl Sandberg under the following description:

There's official power, which comes in the form of a head of state or CEO, and then there's the transformational force of impact, stemming from magnitude of reach and influence. Here are entrepreneurs and early adapters, celebrity role models, activist billionaires and the philanthropists who are healing the world - all ranked by dollars, media presence and impact.

Yet as Swanee Hunt (2007), in an article "Let Women Rule" in Foreign Affairs, reminds us, the progress toward leadership and equal power for women has not been easy or straightforward:

Women have made significant strides in most societies over the last century, but the trend line has not been straight. In recent interviews with hundreds of female leaders in over 30 countries, I have discovered that where women have taken leadership roles, it has been as social reformers and entrepreneurs, not as politicians or government officials. This is unfortunate, because the world needs women's perspectives and particular talents in top positions.

She refers to Francis Fukuyama's 1998 article in Foreign Affairs "Women and the Evolution of World Politics" that speculates women's political leadership would bring about a more cooperative and less conflict-prone world 
of World Politics. She concludes that Fukuyama's promise has yet to be fulfilled. Hunt (2007) suggests that the shift of women from civil society into government will help to develop a healthier political culture and highlights "the advantages women have over men's brawny style of governance, whether because of biology, social roles, or a cascading combination of the two."

Fukuyama's (1998) analysis was strangely double-edged. His article begins with "Chimpanzee Politics" and a reference to Jane Goodall's primate studies at Gombe in order to set up an argument in sociobiology for the claim that a world run by women would be a more highly evolved kind of leadership feminized so to speak - and would be less aggressive than one run by men and therefore more peaceful. This constitutes a form of cultural evolution realizable in the West. Fukuyama's sociobiological argument is supposed to be a knock-down argument of the claim that contemporary feminists make using social constructivism. Fukuyama's extends his argument by reference to "The Not-So Noble Savage" to advance counter-claim to feminists" arguments:

phenomena like aggression, violence, war, and intense competition for dominance in a status hierarchy are more closely associated with men than women (p. 27).

Fukuyama seems to be making all the right moves. He opines:

possibility of domestic peace between wars. The core of the feminist agenda for international politics seems fundamentally correct: the violent and aggressive tendencies of men have to be controlled, not simply by redirecting them to external aggression but by constraining those impulses through a web of norms, laws, agreements, contracts, and the like. In addition, more women need to be brought into the domain of international politics as leaders, officials, soldiers, and voters. Only by participating fully in global politics can women both defend their own interests and shift the underlying male agenda (p. 37).

Here's the kick-back from Fukuyama explained by Ann Tickner (1999: 3):

While he sees a possibility of this 'feminized world' being realized in the West, Fukuyama argues for keeping men in charge as protection against the non-Western world where aggressive men will continue to dominate politics. This article claims that, in spite of seemingly sympathetic attitudes toward feminist politics, Fukuyama's argument is deeply conservative and has the effect of not only keeping women out of politics, but also reinforcing recent arguments in IR about civilizational conflicts.

Where feminists locate violence in patriarchal culture Fukuyama's argument locates violence in biology and he wants emphasize how hard-wired we are and therefore how violence is deep-seated and difficult to shift. Tickner 
(1999) suggests that Fukuyama's arguments divert out attention away from understanding and taking action against the disadvantages faced by the majority of women in the world including unequal social structures and hierarchical gender structures.

The hard-won gains of women in the last hundred years point to palpable political improvements in the distribution of power and in political, social and economic rights that women have struggled for over many generations. These are now more clearly seen in a global sense than any other time in human history but the explanatory narrative ought to be more about women's solidarity (also sociobiological?) and women's political representation in national and international contexts - a story that inescapably involves education considered in the broadest sense: not only formal education and women's increasing access to all levels but also the active forms of informal education that took place with conscientization and the birth of the modern women's movement that is till unfolding.

Pamela Paxton, Melanie M. Hughes, and Jennifer L. Green (2006) investigating "The International Women's Movement and Women's Political Representation, 1893-2003" begin:

Women's participation in politics has increased dramatically over the past 100 years. In 1890 , women did not have the right to vote anywhere in the world. Currently, only one country, Saudi Arabia, denies women the right to vote. In 1907, Finland became the first country to elect a female member of parliament. Currently, women make up almost $50 \%$ of the national legislature in countries such as Sweden and Rwanda. The first country to reach $10 \%$ women in its national legislature was the Union of Soviet Socialist Republics (USSR), in 1946. In $2005,60 \%$ of countries had at least $10 \%$ women in their national legislatures. Although women still are substantially underrepresented in politics in most countries of the world (Inter-Parliamentary Union 2006), they certainly have made remarkable gains over time (pp. 898-899).

Their article does not make clear how uneven the progress has been on winning the vote (for example, how late it was in France, 1948 and Switzerland, 1972). Yet they do mention the growth and discourse of the international women's movement that encouraged global expansion of women's political participation global institutionalization of women's equality.

By comparison, Kristina Horn Sheeler and Karrin Vasby Anderson (2014: 474) comments on the lack of representation.

Women worldwide lack representation in electoral politics. As of February 2013, women account for only 18 of the world's heads of government and approximately $20 \%$ of the world's parliaments. The United States has never elected a woman president and recently 
rose to 77 th place worldwide in a ranking of women in national parliaments. Rwanda leads the list with $56 \%$ female representation in its Chamber of Deputies, the first country in the world to elect a majority of women to its legislative assembly. The 113th U.S. Congress consists of $18 \%$ women.

The gender-egalitarian reform of Western societies after WWII began as a set of policies addressing labor market participation and education, and became the basis for the Nordic gender regime "characterized by the ideal that men and women both should be breadwinners and responsible for the upbringing of children" (Gunnel Gustafsson and Kerstin Kolam, 2008: 28). Gustafsson and Kolam comment that "Swedish society is more gender egalitarian than most others" (p. 29). In the 1980s policies of state feminism were formulated to empower women with the expectation that a greater number of women parliamentarians would result in a more gender-equal society. This has generally been the case with female parliamentarians doubling since the 1970s to some $45 \%$ and with commensurate numbers of female ministers.

\section{Shattering the Glass Ceiling}

It could be argued that the present constellation of female world leaders represents a new high point not only in the election of female world leaders but also the coming exercise of feminine world power in terms of politics that address women's issues (e.g., pay equity, women's rights) and also purported bring a women's style of leadership to bear on complex problems facing the world (Fukuyama, 1997).

At the time of writing Theresa May assumed the leadership of the Conservative Party (on July 11) and the mantle as Prime Minister of UK on July $13^{\text {th }}$ in the immediate aftermath of Brexit. Angela Merkel has been the Chancellor of Germany since 2005 and leader of the Christian Democratic Union since 2000. Janet Yellan is Federal Reserve Chair, Janet Napolitano is Secretary of Homeland Security and Samatha Power is Ambassador of the United States to the United Nations. Park Geun-hye has been President of South Korea since 2013; Erna Solberg has been prime Minister of Norway since 2013; Sheikh Hasina Wajed has been Prime Minister of Bangladesh since 2009; Tsai Ing-wen was elected President of Taiwan in 2016. Nicola Sturgeon is First Member of Scotland since 2014. There are female heads of state in Liberia, Malta, Croatia, Namibia, Mauritius, Nepal, Poland, the Marshall Islands, not counting queens, governors-general, chairpersons of executive organisations, ministers and government secretaries.

In addition, Christine Lagarde has been Managing Director of the IMF since 2011 and some six women are among the twelve candidates currently vying for the top position at the UN in December 2016 including Helen Clarke 
the ex-Prime Minister of NZ and current UN Adminsitrator. Perhaps the most important upcoming position is that of the possible election of Hillary Clinton as the next president of the USA to be decided on November 8 , 2016. The notion of "the woman card," "the only card she has" as Trump remarked, has become large. Clinton polls better among women (and Trump polls better among man). Clinton retorted: "The other day, Mr. Trump accused me of playing the, quote, "woman card." Well, if fighting for women's health care and paid family leave and equal pay is playing the woman card, then deal me in." pink woman cards for fund and political raising with huge benefits. Clinton's website prominently features "women's rights and opportunity" focusing on a host of issues: close the pay gap, paid leave, affordable child care, increase the minimum wage, enhance Social Security, confront violence against women, planned parenthood and so on. ${ }^{3}$

Should Clinton succeed in her presidential bid it could be argued that the world faces a new feminine regime of power that has developed an extremely pervasive and comprehensive system in the Western alliance. Suzanne Nossel (2016) writing for Foreign Affairs an article entitled "The Women on Top Theory" that carries the subheading; "Studies show that when women comprise around $25 \%$ of a group, their influence dramatically reshapes culture. Is 2016 the year women change the world?" Nossel (2016) refers to Jay NewtonSmall's (2016) book Broad Influence: How Women Are Changing the Way America Works. Newton-Small examines how women's roles in the public and private sector have become transforming arguing that once women reach "critical mass," or $20-30 \%$, in a group, change starts to happen for the better. The idea started when she was covering the Senate and their proportion had reached $20 \%$ for the first time: They produced $75 \%$ of the major legislation that passed in the Senate that year [2014]. As it turns out, Nossel (2016) reports, the "critical mass" idea originated with Rosabeth Moss Kanter's (1977) article "Some Effects of Proportions on Group Life: Skewed Sex Ratios and Responses to Token Women" in the American Journal of Sociology. Kanter (1977: 965) who holds the Ernest L. Arbuckle Professorship at Harvard Business School suggests that "Proportions, that is, relative numbers of socially and culturally different people in a group, are seen as critically shaping interaction dynamics."

They are some signs that women in public office in each of the three parts of government have or are rapidly approaching the $20 \%$ figure. Should Hillary Clinton become the first women in the White House, the question is whether this "critical mass" translates into a change of leadership style that is recognizably feminine and that can de-escalate the current conflicts as well as creating a lasting impact on the evolving global political landscape. 


\section{NOTES}

1. See http://www.jjmccullough.com/charts_rest_female-leaders.php based on data from Rulers.org, WorldStatesmen.org, or Regnal Chronologies. See also the following sites: https://en.wikipedia.org/wiki/List_of_elected_and_appointed_female_ heads_of_state; http://planetrulers.com/category/female-leaders/ and http://www. guide2womenleaders.com/Current-Women-Leaders.htm.

2. Reported in the New York Times, http://www.nytimes.com/politics/first-draft /2016/05/02/hillary-clinton-cashes-in-on-donald-trumps-womans-card-comments/. See also Lepore (2016), "The Woman Card."

3. See https://www.hillaryclinton.com/issues/womens-rights-and-opportunity/. Clinton has has been criticized for being a neoliberal espousing hypermasculine values see http://www.huffingtonpost.com/anis-shivani/feminists-stop-obfuscatin_b_98355 10.html

\section{REFERENCES}

Fukuyama, Francis (1998), "Women and the Evolution of World Politics," Foreign Affairs 77(5): 24-40.

Kanter, Rosabeth Moss (1977), "Some Effects of Proportions on Group Life: Skewed Sex Ratios and Responses to Token Women," American Journal of Sociology 82(5): 965-990.

Lepore, Jill (2016), "The Woman Card," The New Yorker, at http://www.newyorker. com/magazine/2016/06/27/hillary-clinton-and-the-history-of-women-in-american-politics

Newton-Small, Jay (2016), Broad Influence: How Women Are Changing the Way America Works. New York: Time.

Nossel, Suzanne (2016), "The Women on Top Theory" Foreign Affairs, http:// foreignpolicy com/2016/07/25/the-glass-cliff-women-better-leaders-in-crisistheresa-may-hillary-clinton-theresa-may-social-science/

Sheeler, Kristina Horn, and Karrin Vasby Anderson (2014), "Gender, Rhetoric, and International Political Systems: Angela Merkel's Rhetorical Negotiation of Proportional Representation and Party Politics," Communication Quarterly 62(4): 474-495.

Shivani, Anis (2016), "Hillary Clinton Does Not Represent Values that Help Women," Huffington Post, http://www.huffingtonpost.com/anis-shivani/feminists-stopobfuscatin_b_9835510.html

Tickner, Ann. J. (1999), "Why Women Can't Run the World: International Politics according to Francis Fukuyama," International Studies Review 1(3): 3-11. 